\title{
Kompostiranje agroindustrijskog otpada, biootpada i biorazgradljivog komunalnog otpada u adijabatskom reaktoru
}

\author{
D. Kučić Grgić, ${ }^{a *} F$. Briški, ${ }^{a}$ V. Ocelić Bulatović, \\ M. Vuković Domanovac, ${ }^{a}$ T. Domanovac, ${ }^{c}$ M. Šabić Runjavec, ${ }^{a}$ \\ M. Miloloža i M. Cvetnića \\ a Fakultet kemijskog inženjerstva i tehnologije, Sveučilište u Zagrebu, Hrvatska \\ b Metalurški fakultet, Sveučilište u Zagrebu, Hrvatska \\ cIPZ Uniprojekt TERRA d. o. o., Hrvatska
}

\begin{abstract}
Sažetak
U ovom radu provedena je biološka obrada agroindustrijskog otpada (P1), biootpada (P2) i biorazgradljivog komunalnog otpada (P3) procesom kompostiranja u adijabatskom reaktoru tijekom 21 dana. U pokusima P1, P2 i P3 postignuta je maksimalna

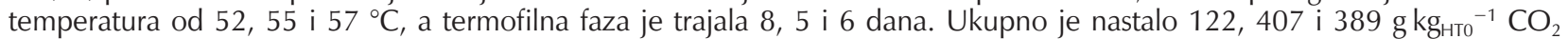
odnosno 89, 148 i $559 \mathrm{mg} \mathrm{kg}_{\mathrm{HT}_{0}}{ }^{-1} \mathrm{NH}_{3}$. pH-vrijednost je na početku procesa bila u neutralnom području, a na kraju u blago lužnatom području. Vlažnost supstrata se povećala za oko $5 \%$, dok se omjer $\mathrm{C} / \mathrm{N}$ smanjivao uslijed smanjenja udjela organskog C te povećanja udjela N. Shodno navedenom, postignuta je konverzija od 48 \%, 71 \% odnosno 56 \% u pokusima P1, P2 i P3.
\end{abstract}

\section{Ključne riječi}

Agroindustrijski otpad, biootpad, biorazgradljivi komunalni otpad, kompostiranje, adijabatski reaktor

\section{Uvod}

Posljednjih nekoliko desetljeća štetan utjecaj čovjeka na okoliš naglo se širi i raste iz dana u dan. Najznačajniji razlozi rasta su razvoj industrije, tehnološki napredak i porast broja stanovnika. Znanstvenici su postali svjesni posljedica koje bi trend rasta onečišćenja okoliša mogao prouzročiti, a neke od posljedica već su prisutne. Jedan od najvećih problema današnjice u pogledu zaštite okoliša je količina otpada koji nastaje te njegovo zbrinjavanje.

Otpadom se smatra svaka tvar ili objekt što ga posjednik odbaci, namjerava odbaciti ili je dužan odbaciti. ${ }^{1}$ Otpad se generira kroz upotrebu proizvoda u društvu u cjelini, kao i u proizvodnim procesima i uslugama gospodarskih subjekata. Odlaganje otpada na odlagališta nije zadovoljavajuće rješenje jer je sanacija odlagališta vrlo skupa, odnosno mora se provoditi kontinuirano kako bi se smanjili negativni utjecaji otpada na okoliš i prirodne resurse (onečišćenje površinskih voda, podzemnih voda, tla, zraka, uključujući efekt stakleničkih plinova).

Ekološki prihvatljivim načinom zbrinjavanja biorazgradljivog otpada smatra se proces kompostiranja koji se intenzivno primjenjuje u razvijenim zemljama. Kompostiranje dolazi od latinske riječi compositum, što u prijevodu znači mješavina, a odnosi se na raznolikost supstrata koji zajednice mikroorganizama u aerobnim uvjetima prevode u stabilan produkt-kompost uz oslobađanja plinova (ugljikov dioksid, amonijak), topline i vode. ${ }^{2}$ Navedenim procesom mogu se zbrinuti različiti biorazgradljivi otpadi među koje se ubrajaju i pojedini agroindustrijski otpadi, biootpad i biorazgradljivi

*Autor za dopisivanje: doc. dr. sc. Dajana Kučić Grgić, e-pošta: dkucic@fkit.hr komunalni otpad. Da bi došlo do uspješnog procesa kompostiranja, potrebno je zadovoljiti početne fizikalno-kemijske i mikrobiološke karakteristike, odnosno podesiti pH-vrijednost, vlagu, protok zraka, veličinu čestica, mikroorganizme i dr., te se iz tog razloga često provodi ko-kompostiranje, odnosno kompostiranje različitih vrsta otpada.

$\cup$ agroindustrijski otpad ubraja se i duhanski otpad, otpad od prerade grožđa i otpad nastao proizvodnjom maslinova ulja. Duhanski otpad nastaje u primarnoj proizvodnji, ali i tijekom procesa proizvodnje cigareta, te se klasificira kao opasan i toksičan ukoliko sadrži više od 0,05 \% nikotina. ${ }^{3}$ Nikotin je dobro mješljiv s vodom i postoji opasnost da migrira u okoliš, u podzemne vode, kao procjedna voda duhanskog otpada. Također, duhanski otpad sadrži veliku količinu organske tvari (TOC > $200 \mathrm{mg} \mathrm{dm}^{-3}$ ) zbog čega tu vrstu otpada nije dopušteno zajedno s komunalnim otpadom odložiti na odlagalište neopasnog otpada. ${ }^{4-6}$ Otpad nastao proizvodnjom vina (otpad od grožđa) nije sam po sebi opasan, ali može predstavljati rizik za okoliš, počevši od površinskih i dubokih onečišćenja do stvaranja neugodnih mirisa, te se iz tog razloga mora odlagati na odlagalište, spaljivati ili biološki obraditi, što uzrokuje ekonomski i ekološki problem. ${ }^{7}$ Otopina tanina i ostalih komponenti koja se tijekom stajanja izdvaja može prouzročiti smanjenje udjela kisika a može prodrijeti u tlo i podzemne vode. U posljednjih desetak godina pojavljuju se sve stroži zakoni vezani uz zaštitu okoliša, pa je tako, primjerice, odlaganje organskog otpada koji ima više od 5 \% organskog ugljika zabranjeno u zemljama Europske unije uključujući i Hrvatsku. Više od 20 \% vinarske proizvodnje čini otpad, odnosno peteljke, sjemenke, kožica i talog ${ }^{8}$. Vinska komina od crnog grožđa sastoji se od $24 \%$ peteljki, 43 - $54 \%$ potkožice, te $22-32 \%$ sjemenki. $^{9}$ 
Posljednjih desetak godina u mediteranskim krajevima bilježi se povećanje proizvodnje maslinova ulja, a usporedno s time generiranje većih količina neželjenih otpadnih tokova - komine maslina i otpadne vode. $U$ komini masline nalazi se endokarp (koštica), epikarp (kožica), kamenje, voda te ulje koje nije ekstrahirano. Kemijski sastav komine masline ovisi o sorti masline, porijeklu, uvjetima uzgoja te načinu ekstrakcije maslinova ulja. Sastav nastalih otpadnih tokova ovisi o tome je li riječ o diskontinuranom ili kontinuiranom (dvofaznom i trofaznom) procesu proizvodnje maslinova ulja. ${ }^{10,11}$ Kominu masline karakterizira slabo-kisela $\mathrm{pH}$-vrijednost te visoka vrijednost vodljivosti, sadržaja vlage i koncentracije organske tvari i fenola. Organske tvari koje se nalaze u otpadnom toku su lignin, celuloza, hemiceluloza, masne kiseline i proteini. ${ }^{11}$

Prema Zakonu o održivom gospodarenju otpadom, ${ }^{1}$ biootpad je biološki razgradljiv otpad iz vrtova i parkova, hrana i kuhinjski otpad iz kućanstava, restorana, ugostiteljskih i maloprodajnih objekata i sličan otpad iz proizvodnje prehrambenih proizvoda. Biootpad čini gotovo trećinu kućanskog otpada i vrijedna je sirovina za proizvodnju komposta. Biootpad čini $37 \%$ otpada miješanog komunalnog otpada. U Hrvatskoj je 2016. godine ukupno proizvedeno 531581 t biootpada, a od toga je 61093 t odvojeno sakupljeno (11\%), a oporabljeno $35969 \mathrm{t}$, odnosno $7 \% .{ }^{12}$ Prema Pravilniku o nusproizvodima i ukidanju statusa otpada NN 117/14 ${ }^{13}$ dobiveni kompost iz biootpada spada u klasu I, odnosno namijenjen je upotrebi u ekološkoj proizvodnji.

Miješani komunalni otpad je, prema Zakonu o održivom gospodarenju otpadom, svaki otpad iz kućanstva i otpad iz trgovina, industrije i iz ustanova koji je po svojstvima $\mathrm{i}$ sastavu sličan otpadu iz kućanstva, iz kojeg posebnim postupkom nisu izdvojeni pojedini materijali (kao što je papir, staklo i dr.). ${ }^{1}$ Uobičajeno u svojem sastavu sadrži kuhinjski otpad, plastiku, tekstil, papir, karton, staklo i druge materijale. Godine 2016. u Republici Hrvatskoj proizvedeno je 1679765 t komunalnog otpada. Od ukupno proizvedene količine miješanog komunalnog otpada, 77 \% upućeno je na odlagališta, a na oporabu 21 \% komunalnog otpada. Za potrebe pokusa upotrijebljen je biorazgradljivi komunalni otpad koji obuhvaća otpad nastao u kućanstvu i otpad koji je po prirodi i sastavu sličan otpadu iz kućanstva, osim proizvodnog otpada i otpada iz poljoprivrede i šumarstva, koji u svojem sastavu sadrži biološki razgradljiv otpad. ${ }^{1}$

Cilj ovog rada bio je provesti biološku obradu agroindustrijskog otpada (P1), biootpada (P2) i biorazgradljivog komunalnog otpada (P3) procesom kompostiranja u zatvorenom reaktorskom sustavu tijekom 21 dana u svrhu dobivanja komposta. Tijekom procesa kompostiranja pratila se temperatura, $\mathrm{pH}$-vrijednost supstrata, udio vlage i suhe tvari, udio hlapljive tvari, broj mezofilnih i termofilnih bakterija i gljiva te emisija nastalih plinova $\mathrm{CO}_{2}$ i $\mathrm{NH}_{3}$.

\section{Eksperimentalni dio}

\subsection{Materijali}

Supstrati upotrijebljeni u pokusima su agroindustrijski otpad (duhanski otpad, otpad od grožđa i komina maslina), biootpad i biorazgradljivi komunalni otpad. Duhanski otpad dopremljen je iz tvornice duhana Rovinj, Hrvatska. Svježi duhanski otpad osušen je na zraku i skladišten te potom upotrijebljen u pokusima. Otpad od grožđa i komina maslina porijeklom su iz Istre, Agrolaguna d. o. o., Poreč, a pohranjeni su u plastičnim spremnicima u zamrzivaču na temperaturi od $-18{ }^{\circ} \mathrm{C}$. Biootpad upotrijebljen u ovim pokusima sakupljan je u domaćinstvima Grada Zagreba i sastojao se od kore luka, krumpira, mrkve, banane, rajčice, kupusa, naranče, limuna, cikle, tikvice, taloga kave i kruha. Kao strukturni materijal upotrijebljena je pšenična slama. Kosupstrat, lišće, dodano je za podešavanje vlažnosti i omjera $\mathrm{C} / \mathrm{N}$. Biorazgradljivi komunalni otpad prikupljen je sa šireg zagrebačkog područja i sastojao se od $83 \%$ kuhinjskog otpada, 2,2 \% papira i kartona, 1,7 \% plastike, 4,8\% stakla, 1,2\% metala, 3,9\% građevinskog otpada, 0,8 \% kosti i 2,2 \% vrtnog otpada. Sitnicu, kao komponentu u komunalnom otpadu, predstavlja smjesa (voće, povrće, komadi mesa i kože, kruh, lišće, pepeo, prašina, sitna plastika, sitni metali i strugotine, baterije lijekovi, zemlja i kamenje te ostali sitni otpad) koja propada kroz mrežu "sortirke" na kojoj su otvori veličine $40 \mathrm{~mm}$. Prema provedenim ispitivanjima sastava sitnice, približno $75 \%$ prosijane sitnice moguće je kompostirati. Udio "sitnice", tj. prosijanog ostatka u zimskom razdoblju sortiranja iznosi u prosjeku oko $30,7 \%$, a u ljetnom $29,0 \%$. Sitnica je dakle pretežno biorazgradljiva frakcija miješanog komunalnog otpada koja ide na biološku obradu.

\subsection{Analitički postupci}

Tijekom procesa kompostiranja periodično su se izuzimali uzorci iz kompostne mase te se odredio udio suhe tvari, ${ }^{14}$ vlage,${ }^{14}$ hlapljive tvari, ${ }^{14} \mathrm{pH}$-vrijednost supstrata, ${ }^{14}$ udio ugljika i dušika, ${ }^{15}$ volumen kondenzata, $\mathrm{pH}$-vrijednost kondenzata i ukupan broj živih stanica bakterija i gljiva. ${ }^{16}$ Temperatura se svakodnevno određivala. Na izlazu iz reak-

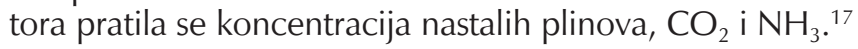

\subsection{Aparatura i provedba procesa kompostiranja}

Pokusi kompostiranja (P1, P2 i P3) provedeni su u adijabatskom reaktoru radnog volumena, $V_{\mathrm{r}}=10 \mathrm{dm}^{3},($ slika 1$),{ }^{18}$ unutarnjeg promjera, $d=212 \mathrm{~mm}$ i visine, $h=330 \mathrm{~mm}$, tijekom 21 dana pri protoku zraka od $0,7 \mathrm{dm}^{3} \mathrm{~min}^{-1} \mathrm{~kg}_{\mathrm{HTO}}{ }^{-1}$. $U$ pokusu P1 proveden je proces kompostiranja agroindustrijskog otpada, u pokusu P2 kompostiranje biootpada i u pokusu P3 kompostiranje biorazgradljivog komunalnog otpada. Zrak je upuhivan na dnu reaktora a protok ulaznog zraka podešen je rotametrom.

Izlaz iz rotametra bio je spojen na bocu ispiralicu koja je postavljena prije ulaza u reaktor. $\mathrm{Na}$ izlazu iz reaktora sakupljan je kondenzat a izlazni plinovi, $\mathrm{CO}_{2} \mathrm{i} \mathrm{NH}_{3}$ apsorbirani su u $1 \mathrm{~mol} \mathrm{dm}^{-3} \mathrm{NaOH}$ odnosno $4 \% \mathrm{H}_{3} \mathrm{BO}_{3}$. Temperaturna osjetila su bila smještena u sredini reaktora, spojena na osobno računalo te se primjenom programa Lab View očitavala temperatura. Uzorkovanje se provodilo kroz otvor na vrhu reaktora. Fizikalno-kemijska karakterizacija supstrata upotrijebljenih u pokusima P1, P2 i P3 dana je u tablici 1. 


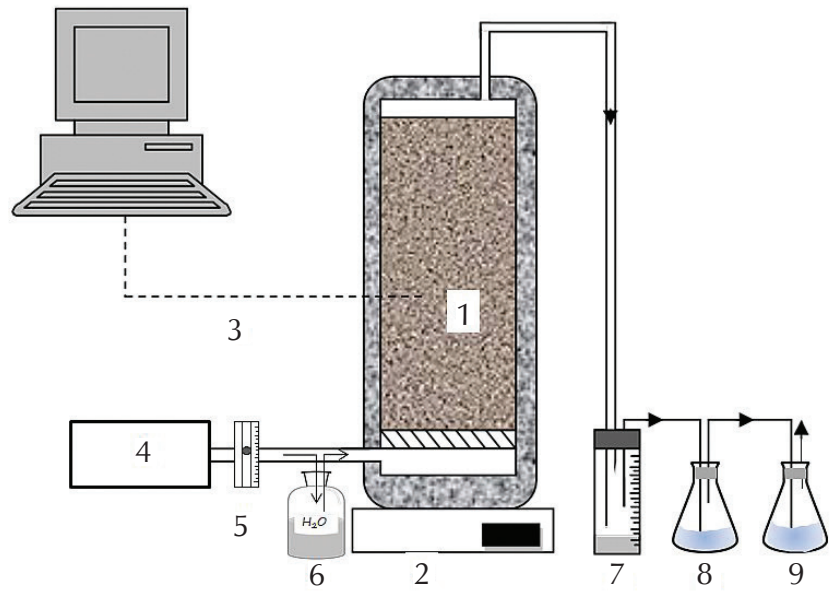

Slika 1 - Shematski prikaz procesa kompostiranja: 1 - reaktor, 2 - vaga, 3 - temperaturna osjetila s akvizicijom, 4 kompresor, 5 - rotametar, 6 - boca ispiralica, 7 - posuda za prikupljanje kondenzata, $8-4 \% \mathrm{H}_{3} \mathrm{BO}_{3}, 9-$ $1 \mathrm{~mol} \mathrm{dm}^{-3} \mathrm{NaOH}$

Fig. 1 - Schematic diagram of composting process: 1 - reactor, 2 - scale, 3 - temperature data acquisition, 4 - compressor, 5 - airflow regulation, 6 - Drechsel bottle, 7 - graduated cylinder; $8-4 \% \mathrm{H}_{3} \mathrm{BO}_{3}, 9-\mathrm{NaOH}, 1 \mathrm{~mol} \mathrm{dm}^{-3}$

\section{Rezultati i rasprava}

Proces kompostiranja proveden je u adijabatskom reaktoru tijekom 21 dana. Kompostirana su tri različita supstrata, agroindustrijski otpad (P1), biootpad (P2) i biorazgradljivi komunalni otpad (P3), s različitim fizikalno-kemijskim i mikrobiološkim značajkama (tablica 1).

Na slici 2 prikazana je promjena temperature tijekom 21 dana kompostiranja u pokusima P1, P2 i P3. Na početku procesa kompostiranja temperatura u pokusima P2 i P3 iznosila je $19{ }^{\circ} \mathrm{C}$ i nakon 24 sata je porasla na $45{ }^{\circ} \mathrm{C}$ i u trećem danu je iznosila $54{ }^{\circ} \mathrm{C}(\mathrm{P} 2)$ odnosno $51{ }^{\circ} \mathrm{C}(\mathrm{P} 3)$. U šestom danu kompostiranja temperatura je lagano počela opadati i do kraja procesa nije više rasla (P2 i P3). Nadalje, vidljivo je da su u pokusima P2 i P3 temperaturne krivulje imale sličan trend. Za razliku od pokusa P2 i P3 u pokusu P1 temperatura nije naglo porasla nego postupno i tek $u$ sedmom danu je prešla $45^{\circ} \mathrm{C}$, a maksimalna temperatura od $53{ }^{\circ} \mathrm{C}$ postignuta je u 12 danu nakon čega je počela opadati. U pokusima P2 i P3 zabilježen je temperaturni skok unutar 24 sata jer se radi o lakorazgradljivim materijalima, odnosno kao supstrati u P2 i P3 upotrijebljeni su biootpad i biorazgradljivi komunalni otpad, dok je u pokusu P1 upotrijebljen agroindustrijski otpad koji je sadržavao duhanski otpad, otpad od grožđa i otpad od masline, koji su toksični i sadrže teško razgradljive materijale (lignin, celulozu i hemicelulozu) te je mikroorganizmima bilo potrebno dulje razdoblje prilagodbe..$^{3-5,7,8,19-24} \mathrm{~S}$ ciljem ubrzanja procesa kompostiranja agroindustrijskog otpada, u

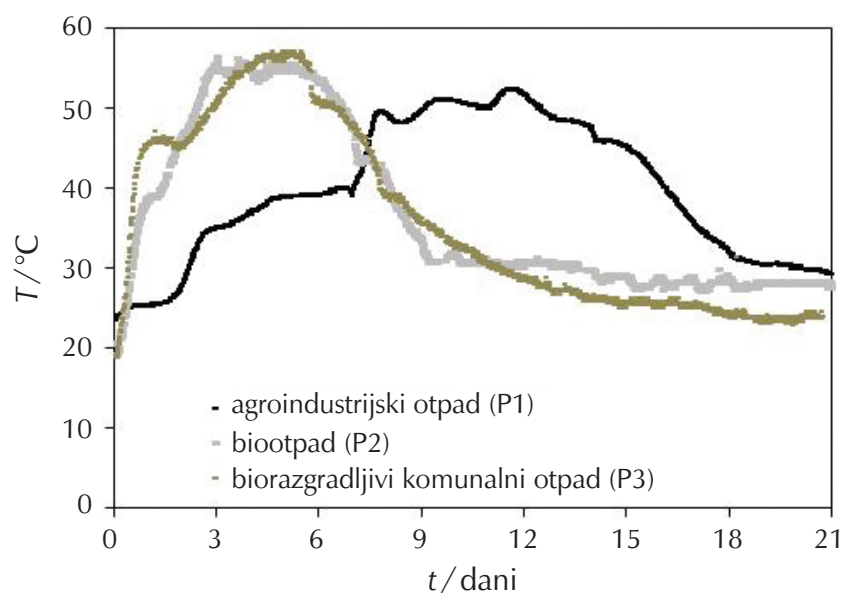

Slika 2 - Promjena temperature u pokusima P1, P2 i P3 tijekom 21 dana kompostiranja

Fig. 2 - Temperature changes in experiments P1, P2, and P3 during 21 days of composting

Tablica 1 - Fizikalno-kemijska karakterizacija mješavine agroindustrijskog otpada, biootpada i biorazgradljivog komunalnog otpada

Table 1 - Physical and chemical characterization of a mixture of agro-industrial waste, biowaste and biodegradable municipal solid waste

\begin{tabular}{|c|c|c|c|}
\hline Supstrat & Agroindustrijski otpad & Biootpad & Biorazgradljivi komunalni otpad \\
\hline$w($ vlage $) / \%$ & 65 & 62 & 62 \\
\hline$w($ suhe tvari) $/ \%$ & 35 & 68 & 38 \\
\hline$w$ (hlapljive tvari) /\% & 82 & 87 & 72 \\
\hline$w(\mathrm{~N}) / \%$ & 1,62 & 1,41 & 2,26 \\
\hline$w(\mathrm{C}) / \%$ & 46,22 & 48,26 & 40,01 \\
\hline omjer C/N/- & 29 & 34 & 18 \\
\hline $\mathrm{pH}$-vrijednost $\mathrm{substrata}_{\text {- }} /$ & 6,23 & 6,26 & 6,94 \\
\hline $\mathrm{st}_{\text {bakterija }} \mathrm{g}_{\mathrm{ST}}{ }^{-1} 37^{\circ} \mathrm{C}$ & $9,60 \cdot 10^{7}$ & $2,23 \cdot 10^{7}$ & $6,21 \cdot 10^{8}$ \\
\hline $\mathrm{st}_{\text {bakterija }} \mathrm{g}_{\mathrm{ST}}{ }^{-1} 50^{\circ} \mathrm{C}$ & $1,60 \cdot 10^{6}$ & $1,94 \cdot 10^{6}$ & $1,28 \cdot 10^{8}$ \\
\hline $\mathrm{st}_{\text {gljiva }} \mathrm{g}_{\mathrm{ST}}{ }^{-1} 28^{\circ} \mathrm{C}$ & $1,94 \cdot 10^{8}$ & $1,40 \cdot 10^{6}$ & $9,89 \cdot 10^{6}$ \\
\hline $\mathrm{st}_{\mathrm{gljiva}} \mathrm{g}_{\mathrm{ST}}{ }^{-1} 50^{\circ} \mathrm{C}$ & $9,88 \cdot 10^{2}$ & $1,23 \cdot 10^{2}$ & $5,81 \cdot 10^{4}$ \\
\hline
\end{tabular}




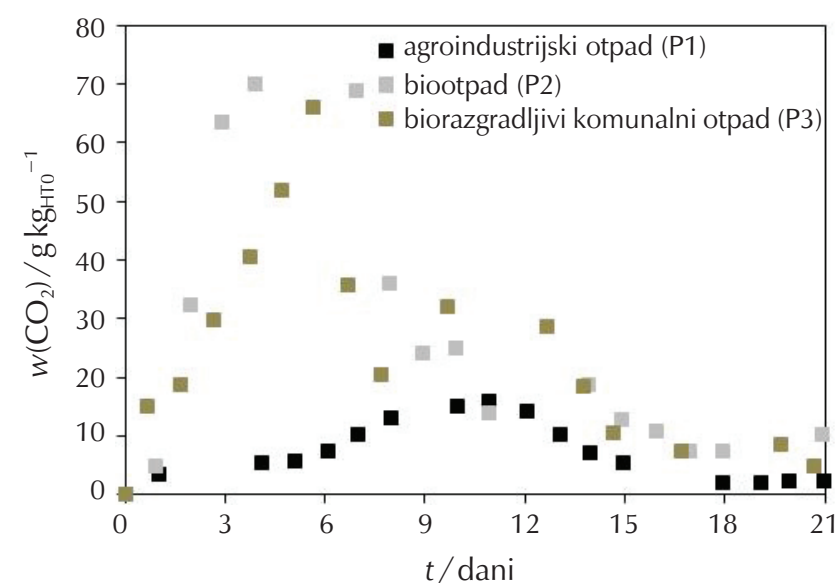

Slika 3 - Maseni udio $\mathrm{CO}_{2}$ u struji zraka na izlazu iz reaktora u pokusima P1, P2 i P3 tijekom 21 dana kompostiranja

Fig. 3 - Evolved $\mathrm{CO}_{2}$ in exhaust air in experiments $\mathrm{P} 1, \mathrm{P} 2$, and P3 during 21 days of composting

pokus P1 mogu se inokulirati mikroorganizmi, poput Phanerochaete chrysosporium i Trichoderma reesei, koji imaju mogućnost razgradnje lignoceluloznog otpada. ${ }^{25-27}$

Na slici 3 može se vidjeti da se porastom temperature povećava i udio $\mathrm{CO}_{2}$ u pokusima P1, P2 i P3, odnosno krivulja $\mathrm{CO}_{2}$ prati krivulju temperature. Maksimalan udio $\mathrm{CO}_{2}$ postignut je pri najvišoj temperaturi zbog intenzivne biorazgradnje organske tvari. Padom temperature udio $\mathrm{CO}_{2}$ u struji zraka na izlazu iz reaktora u svim pokusima se smanjivao, što se može usporediti sa smanjenom mikrobiološkom aktivnošću. ${ }^{2,18,19}$ Najviše $\mathrm{CO}_{2}$ je nastalo u pokusima P2 (406,48 $\left.\mathrm{g} \mathrm{kg}_{\text {нто }}{ }^{-1}\right)$ i P3 $\left(389,29 \mathrm{~g} \mathrm{~kg}_{\text {нто }}{ }^{-1}\right)$ (tablica 2) zbog intenzivne mikrobiološke razgradnje, što se slaže i s postignutom konverzijom od 71 i $56 \%$ u pokusima P2 i P3 (slika 4, tablica 2). U pokusu P1 postignuta je konverzija od $48 \%$, a nastalo je $121,76 \mathrm{~g} \mathrm{~kg}_{\text {нто }}{ }^{-1} \mathrm{CO}_{2}$. U pokusu P3 $45 \%$ organske tvari se razgradilo unutar 7 dana, dok u pokusu P2 unutar 15 dana a razlog tomu mogu biti lišće i pšenična slama koji su teško razgradljivi materijali. Nadalje, u pokusima P1 i P3 nastalo je približno isto kondenzata (tablica 2), dok je u pokusu P2 nastalo tri puta manje, a moglo se očekivati da će zbog najveće postignute konverzije nastati najviše kondenzata. Kao jedan od mogućih razloga je taj što se u pokusu P2 kao kosupstrat za kompostiranje upotrebljavalo lišće koje ima veliku upojnu moć.

Promjena temperature (slika 2) izravno je povezana s biokemijskom aktivnošću mikroorganizama, koji razgradnjom organske tvari oslobađaju toplinu i time uzrokuju porast temperature u supstratu. Promjenom temperature u kompostnoj masi dolazi do promjene broja i vrsta članova u mješovitoj kulturi mikroorganizama koji sudjeluju u razgradnji supstrata. Iz tablice 1 te iz tablice 2 može se vidjeti da je ukupan broj mezofilnih i termofilnih bakterija u pokusima P1, P2 i P3 nakon 21 dana bio znatno veći nego u nultome danu. U pokusima P1 i P2 broj mezofilnih i termofilnih bakterija eksponencijalno je porastao, dok u pokusu P3 nije imao tako nagli porast broja, što možemo pripisati većem udjelu organske tvari u pokusima P1 i P2 (tablica 1). ${ }^{18,19,23,24}$ Broj mezofilnih gljiva je u svim pokusi-

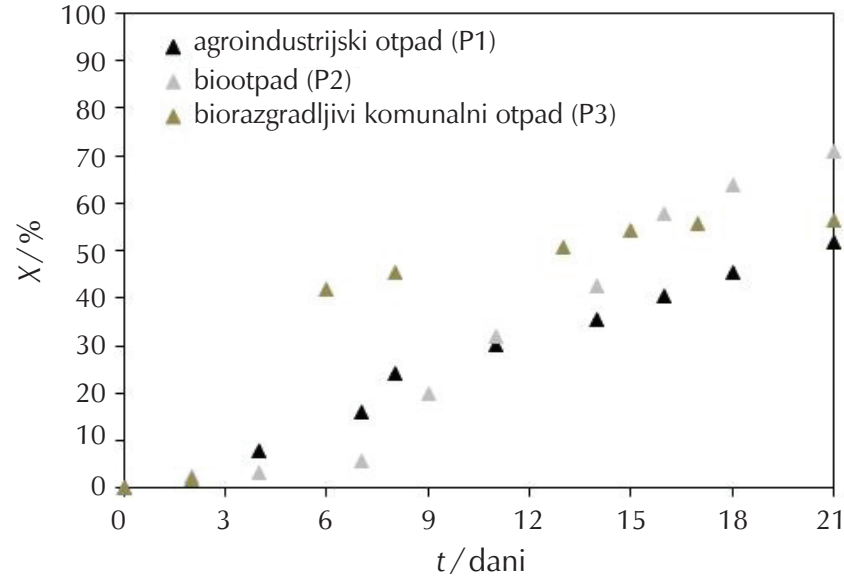

Slika 4 - Konverzija organske tvari u pokusima P1, P2 i P3 tijekom 21 dana kompostiranja

Fig. 4 -Conversion of organic matter in experiments P1, P2, and P3 during 21 days of composting

ma na kraju procesa bio niži u odnosu na nulti dan, a termofilnih nešto viši, iako brojčano su prevladavale mezofilne gljive (tablice 1 i 2). Razlog tome može biti što je unutar zajednice termofilnih gljiva i dio gljiva kojima pogoduju i mezofilne i termofilne temperature, te je prelaskom u drugu mezofilnu fazu njihov ukupni broj nešto viši u odnosu na početak. Poznato je da je ukupan broj mezofilnih gljiva na početku procesa veći jer gljivama (kvascima) odgovara blago kiselo područje, a pH-vrijednost je na početku procesa u svim pokusima bila oko 6,5 , a na kraju iznad 8 (tablica 1, slika 5). ${ }^{2}$

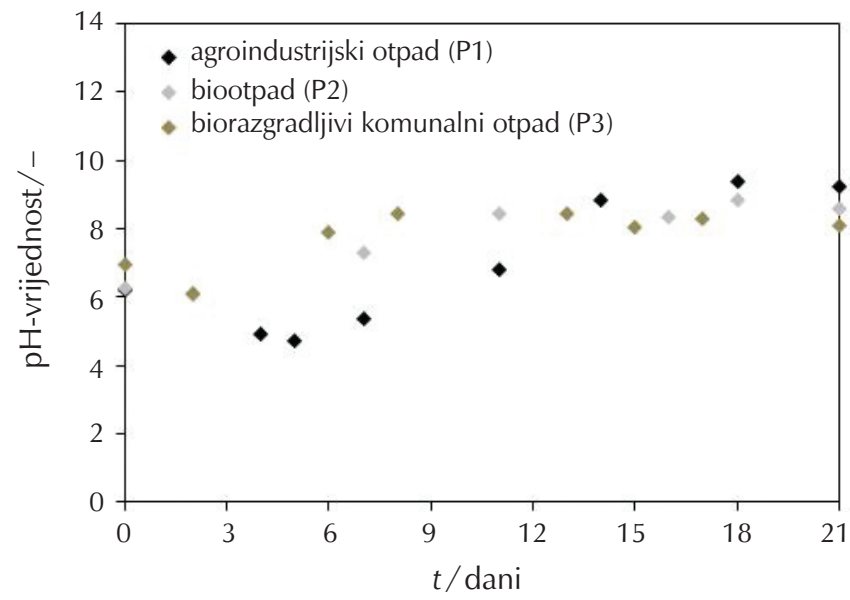

Slika 5 - Promjena pH-vrijednosti u pokusima P1, P2 i P3 tijekom 21 dana kompostiranja

Fig. 5 -Changes in pH-value in experiments P1, P2, and P3 during 21 days of composting

pH-vrijednost u pokusu P2 je u prvih deset dana rasla i postigla vrijednost oko 8,5 te se do kraja procesa nije znatno mijenjala. Nasuprot pH-vrijednosti u P2, pH-vrijednost se u pokusima P1 i P3 na početku procesa smanjila zbog 
Tablica 2 - Rezultati dobiveni procesom kompostiranja u pokusima P1, P2 i P3

Table 2 - Results of composting experiments, P1, P2, P3

\begin{tabular}{|c|c|c|c|}
\hline Supstrat & Agroindustrijski otpad & Biootpad & Biorazgradljivi komunalni otpad \\
\hline$w($ vlage $) / \%$ & 70 & 73 & 70 \\
\hline$w($ suhe tvari) $/ \%$ & 30 & 27 & 30 \\
\hline$w$ (hlapljive tvari) $/ \%$ & 73 & 70 & 53 \\
\hline$w(\mathrm{~N}) / \%$ & 2,25 & 3,89 & 3,64 \\
\hline$w(\mathrm{C}) / \%$ & 43,51 & 39,18 & 33,89 \\
\hline omjer C/N/- & 19 & 10 & 9 \\
\hline pH-vrijednost supstrata $_{\text {I }} /-$ & 9,24 & 8,56 & 8,11 \\
\hline $\mathrm{st}_{\text {bakterija }} \mathrm{g}_{\mathrm{ST}}{ }^{-1} 37^{\circ} \mathrm{C}$ & $5,87 \cdot 10^{9}$ & $2,09 \cdot 10^{9}$ & $9,51 \cdot 10^{8}$ \\
\hline $\mathrm{st}_{\text {bakterija }} \mathrm{g}_{\mathrm{ST}}{ }^{-1} 50{ }^{\circ} \mathrm{C}$ & $5,88 \cdot 10^{9}$ & $2,65 \cdot 10^{9}$ & $2,61 \cdot 10^{8}$ \\
\hline $\mathrm{st}_{\mathrm{glj \textrm {jiva }}} \mathrm{g}_{\mathrm{ST}}{ }^{-1} 28^{\circ} \mathrm{C}$ & $1,56 \cdot 10^{7}$ & $1,03 \cdot 10^{5}$ & $4,73 \cdot 10^{5}$ \\
\hline $\mathrm{st}_{\mathrm{glj} \text { jiva }} \mathrm{g}_{\mathrm{ST}}{ }^{-1} 50^{\circ} \mathrm{C}$ & $1,62 \cdot 10^{3}$ & $7,06 \cdot 10^{4}$ & $1,36 \cdot 10^{6}$ \\
\hline$V_{\text {kondenzata }} / \mathrm{ml}$ & 364 & 122,5 & 414,42 \\
\hline pH-vrijednost $t_{\text {kondenzata }} /-$ & 8,9 & 8,92 & 7,5 \\
\hline$V_{\text {procjedne vode }} / \mathrm{ml}$ & 0 & 75 & 0 \\
\hline$w\left(\mathrm{CO}_{2}\right) / \mathrm{g} \mathrm{kg}_{\mathrm{HTT}}{ }^{-1}$ & 121,76 & 406,48 & 389,29 \\
\hline$w\left(\mathrm{NH}_{3}\right) / \mathrm{g} \mathrm{kg}_{\mathrm{HTO}}{ }^{-1}$ & 88,79 & 147,35 & 558,88 \\
\hline$T_{\max } /{ }^{\circ} \mathrm{C}$ & 52,38 & 55,48 & 56,91 \\
\hline konverzija/\% & 48 & 71 & 56 \\
\hline
\end{tabular}

stvaranja organskih kiselina. ${ }^{28} \mathrm{U}$ procesu kompostiranja je $\mathrm{pH}$-vrijednost kompostne mase u rasponu od slabo kisele do slabo lužnate vrijednosti, $\mathrm{pH} \approx 5,5-8,0 .{ }^{2} \mathrm{U}$ pokusima P1, P2 i P3 pH-vrijednost je rasla do 15 dana, 11 dana odnosno do 8 dana kada se više nije znatno mijenjala. Do porasta $\mathrm{pH}$-vrijednosti kompostne mase dolazi zbog stvaranja amonijevih iona $\left(\mathrm{NH}_{4}{ }^{+}\right)$kao rezultat amonifikacije. ${ }^{20,29}$ Plin amonijak nastaje tijekom razgradnje organskih dušikovih spojeva a njegova koncentracija ovisi o pH-vrijednosti kompostne mase, omjeru $\mathrm{C}: \mathrm{N}$ i temperaturi. ${ }^{20}$

S obzirom na to da je prinos procesa amonifikacije u kompostnoj masi veći od imobilizacije amonijaka, dolazi do akumulacije $\mathrm{NH}_{4}{ }^{+} / \mathrm{NH}_{3}$, povećanja $\mathrm{pH}$-vrijednosti kompostne mase te $\mathrm{NH}_{3}$ aeracijom biva otplinjen. $U$ pokusu P3 nastalo je najviše amonijaka $\left(558,88 \mathrm{mg} \mathrm{kg}_{\mathrm{HTO}}{ }^{-1}\right)$, dok u pokusima P1 i P2 četiri puta manje (slika 6). Razlog tome može biti izrazito nizak omjer C/N (18/1) (tablica 1) u pokusu P3, dok je u pokusima P1 i P2 iznosio oko 30/1, što znači da je supstrat, biorazgradljivi komunalni otpad, koji je upotrijebljen u pokusu P3, izrazito bogat dušikom, a manje ugljikom (tablica 1). Nadalje, može se primijetiti (slika 6) da se amonijak detektira u drugoj mezofilnoj fazi, odnosno u pokusu P1 u 10. danu, u pokusu P2 u 16. danu i P3 u 5. danu.

\section{Zaključak}

S ciljem razvoja ekonomski prihvatljivog i ekološki održivog procesa zbrinjavanja otpada u ovom je radu provedena biološka obrada agroindustrijskog otpada (P1), biootpada

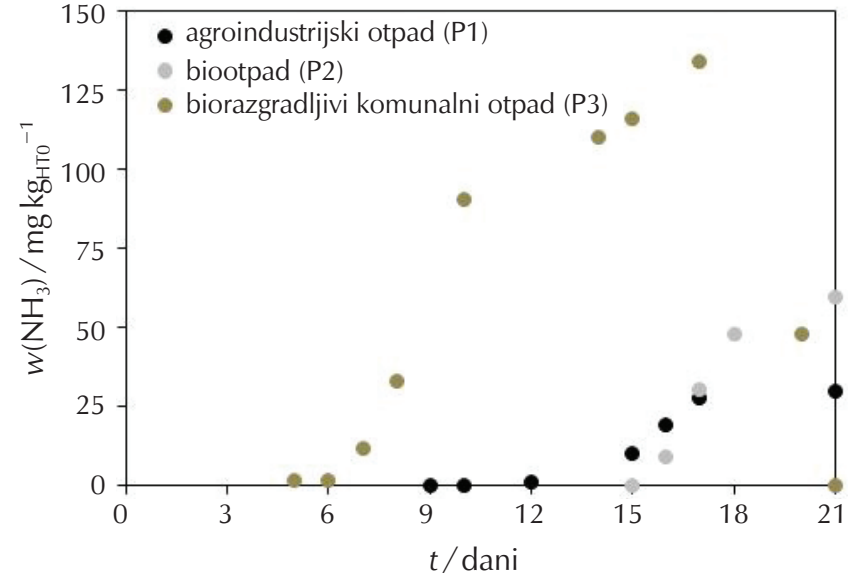

Slika 6 - Maseni udio $\mathrm{NH}_{3}$ u struji zraka na izlazu iz reaktora u pokusima P1, P2 i P3 tijekom 21 dana kompostiranja

Fig. 6 - Evolved $\mathrm{NH}_{3}$ in exhaust air in experiments P1, P2, and P3 during 21 days of composting

(P2) i biorazgradljivog komunalnog otpada (P3) procesom kompostiranja.

Na temelju postignute maksimalne temperature i trajanja termofilne faze može se zaključiti da je procesom kompostiranja navedenih otpada došlo do higijenizacije otpada, odnosno do uništavanja patogenih mikroorganizama. U pokusima P1, P2 i P3 postignuta je konverzija od $48 \%$, $71 \%$ odnosno $56 \%$, što ukazuje na smanjenje mase vlažnog supstrata za više od 50 \%. Ukupna količina nastalih 
plinova, $\mathrm{CO}_{2}$ i $\mathrm{NH}_{3}$, u izlaznoj struji zraka u pokusima P1, P2 i P3 iznosila je 121,76 $\mathrm{g} \mathrm{kg}_{\mathrm{HT} 0}{ }^{-1}, 406,48 \mathrm{~g} \mathrm{~kg}_{\mathrm{HTO}}{ }^{-1}$ i 389,29 $\mathrm{g} \mathrm{kg}_{\mathrm{HTO}}{ }^{-1}$ odnosno 88,79 $\mathrm{mg} \mathrm{kg}_{\text {нто }}{ }^{-1}$, 147,35 $\mathrm{mg} \mathrm{kg}_{\mathrm{HTO}}{ }^{-1}$ i $558,88 \mathrm{~g} \mathrm{~kg}_{\mathrm{HTO}}{ }^{-1}$. Na kraju procesa kompostiranja pH-vrijednost je u svim provedenim pokusima bila u blago lužnatom području, produkt je bio tamno-smeđe boje, vlažnosti oko $70 \%$, te su se gljive ponovno aktivirale, što ukazuje na početak zrenja komposta. Na temelju iznesenih zaključaka, navedeni otpadi mogu se učinkovito zbrinuti procesom kompostiranja, a kako bi se minimizirao učinak plinova na okoliš, u supstrat se mogu dodati materijali poput zeolita koji će na sebe vezati plinove i višak vode, čime će se ujedno smanjiti i volumen nastalih procjednih voda. Prema dosadašnjim istraživanjima navedeni zeolit doprinosi kvaliteti komposta.

\section{ZAHVALA}

Ovim putem zahvaljujemo Hrvatskoj zakladi za znanost koja je u sklopu projekta Modelling of Environmental Aspects of Advanced Water Treatment for Degradation of Priority Pollutants (MEAoWT) (IP-09-2014-7992) financirala znanstveno-istraživački rad.

\section{Popis kratica i simbola List of abbreviations and symbols}

\begin{tabular}{|c|c|}
\hline C & $\begin{array}{l}\text { - ugljik } \\
\text { - carbon }\end{array}$ \\
\hline $\mathrm{CO}_{2}$ & $\begin{array}{l}\text { - ugljikov dioksid } \\
\text { - carbon dioxide }\end{array}$ \\
\hline HT & $\begin{array}{l}\text { - hlapljiva tvar } \\
\text { - volatile matter (VM) }\end{array}$ \\
\hline 0 & $\begin{array}{l}\text { - vrijednost u } 0 \text { danu } \\
\text { - value at day } 0\end{array}$ \\
\hline $\mathrm{N}$ & $\begin{array}{l}\text { - dušik } \\
\text { - nitrogen }\end{array}$ \\
\hline $\mathrm{NH}_{3}$ & $\begin{array}{l}\text { - amonijak } \\
\text { - ammonia }\end{array}$ \\
\hline st & $\begin{array}{l}\text { - stanica } \\
\text { - cell }\end{array}$ \\
\hline ST & $\begin{array}{l}\text { - suha tvar } \\
\text { - dry matter }\end{array}$ \\
\hline$T$ & $\begin{array}{l}\text { - temperatura, }{ }^{\circ} \mathrm{C} \\
\text { - temperature, }{ }^{\circ} \mathrm{C}\end{array}$ \\
\hline$V$ & $\begin{array}{l}\text { - volumen, } \mathrm{dm}^{3} \\
\text { - volume, } \mathrm{dm}^{3}\end{array}$ \\
\hline$V_{\mathrm{r}}$ & $\begin{array}{l}\text { - radni volumen, } \mathrm{dm}^{3} \\
\text { - working volume, } \mathrm{dm}\end{array}$ \\
\hline$w$ & $\begin{array}{l}\text { - maseni udio, } \% \\
\text { - mass fraction, } \%\end{array}$ \\
\hline$X$ & $\begin{array}{l}\text { - konverzija, } \% \\
\text { - conversion, } \%\end{array}$ \\
\hline
\end{tabular}

\section{Literatura \\ References}

1. Zakon o održivom gospodarenju otpadom NN 94/13, 73/17, $14 / 19$.

2. R. T. Haug, The practical handbook of compost engineering, Lewis, Boca Raton (1993).

3. A. Piotrowska-Cyplik, A. Olejnik, P. Cyplik, J. Dach, Z. Czarnecki, The kinetics of nicotine degradation, enzyme activities and genotoxic potential in the characterization of tobacco waste composting, Bioresour. Technol. 100 (2009) 5037-5044, doi: https://doi.org/10.1016/j.biortech.2009.05.053

4. C. R. Cardoso, M. R. Miranda, K. G. Santos, C. H. Ataíde, Determination of kinetic parameters and analytical pyrolysis of tobacco waste and sorghum bagasse, J. Anal. Appl. Pyrolysis. 92 (2011) 392-400, doi: https://doi.org/10.1016/j. jaap.2011.07.013.

5. F. Briški, N. Horgas, M. Vuković, Z. Gomzi, Aerobic composting of tobacco industry solid waste - simulation of the process, Clean Technol Environ Policy 5 (2003) 295-301, doi: https://doi.org/10.1007/s10098-003-0218-7.

6. Uredba o kategorijama, vrstama i klasifikaciji otpada s katalogom otpada i listom opasnog otpada, NN 50/05, 39/09.

7. D. Pujol, C. Liu, N. Fiol, M. Ángels Olivella, J. Gominho, I. Villaescusa, H. Pereira, Chemical characterization of different granulometric fractions of grape stalks waste, Ind. Crop. Prod. 50 (2013) 494-500, doi: https://doi.org/10.1016/j.indcrop.2013.07.051.

8. M. A. Pedroza, M. Carmona, G. L. Alonso, M. R. Salinas, A. Zalacain, Pre-bottling use of dehydrated waste grape skins to improve colour, phenolic and aroma composition of red wines, Food Chem. 136 (2013) 224-236, doi: https://doi. org/10.1016/j.foodchem.2012.07.110.

9. N. Voća, T. Krička, V. Jurišić, T. B. Savić, A. Matin, Potencijal iskorištenja ostataka nakon proizvodnje vina za dobivanje toplinske energije, Pomology, Viticulture and Enology, $44^{\text {th }}$ Croatian \& $4^{\text {th }}$ International Symposium on Agriculture, Poljoprivredni fakultet Sveučilišta u Osijeku, 2009., str. 880884.

10. M. Niaounakis, C. P. Halvadakis, Olive Processing Waste Management: Literature Review and Patent Survey $2^{\text {nd }}$ Ed., Elsevier, Italy, 2006.

11. J. A. Alburquerque, J. Gonzálvez, D. García, J. Cegarra, Agrochemical characterisation of "alperujo", a solid by-product of the two-phase centrifugation method for olive oil extraction, Bioresour. Technol. 91 (2004) 195-200, doi: https:// doi.org/10.1016/S0960-8524(03)00177-9.

12. Hrvatska agencija za okoliš i prirodu, Pregled podataka o gospodarenju otpadom u RH od 2017. do 2022.

13. Pravilnik o nusproizvodima i ukidanju statusa otpada NN 117/14.

14. Austrian Standards Institute, Austrian standard: Analytical methods and quality control for waste compost. ÖNORM S 2023, 1986., Vienna, Austria.

15. J. M. Bremner, Nitrogen-total, u: D. L. Sparks, A. L. Page, P. A. Helmke, R. H. Loeppert, P. N. Soltanpour, M. A. Tabatabai, C. T. Johnston, M. E. Sumner (Eds.), Methods of soil analysis. Part 3 - chemical methods., American Society of Agronomy, Soil Science Society of America, Madison, Wisconsin, 1996., str. 1089-1108. 
16. F. Briški, N. Kopčić, I. Ćosić, D. Kučić, M. Vuković, Biodegradation of tobacco waste by composting: Genetic identification of nicotine-degrading bacteria and kinetic analysis of transformations in leachate, Chem. Paper. 66 (2012) 11031110, doi: https://doi.org/10.2478/s11696-012-0234-3.

17. I. M. Kolthoff, E. B. Sandel, Inorganic quantitative analysis, Školska knjiga, Zagreb, (1951) 347-352.

18. D. Kučić, N. Kopčić, F. Briški, Zeolite and potting soil sorption of $\mathrm{CO}_{2}$ and $\mathrm{NH}_{3}$ evolved during co-composting of grape and tobacco waste, Chem. Pap. 67 (2013) 1172-1180, doi: https://doi.org/10.2478/s11696-013-0322-z.

19. D. Kučić Grgić, M. Šabić, T. Domanovac, V. Ocelić Bulatović, M. Vuković Domanovac, Composting of agroindustrial waste nad biowaste in a closed reactor, Proceeding book $1^{\text {st }}$ International Conference "The Hollistic Approach to Environment", 2018., str. 382-389.

20. D. Kučić, F. Briški, Emissions of Gases during Composting of Solid Waste, Kem. Ind. 66 (2017) 467-474, doi: https://doi. org/10.15255/KUI.2016.050.

21. M. J. Diaz, E. Madejón, F. López, R. López, F. Cabrera, Optimization of the rate vinasse / grape marc for composting process, Process Biochem. 37 (2002) 1143-1150, doi: https:// doi.org/10.1016/S0032-9592(01)00327-2.

22. F. Briški, Z. Gomzi, A. Hublin, M. Vuković, Aerobno kompostiranje otpadaka voća i povrća: modeliranje procesa, Kem. Ind. 52 (2003) 95-102.

23. D. Kučić Grgić, M. Vuković Domanovac, T. Domanovac, M. Šabić, M. Cvetnić, V. Ocelić Bulatović, Influence of Bacillus subtilis and Pseudomonas aeruginosa BSW and Clinoptilolite addition on the biowaste composting process, AJSE 1 (2019) $1-11$.
24. Ž. Herner, D. Kučić, B. Zelić, Biodegradation of imidacloprid by composting process, Chem. Pap. 71 (2017) 13-20, doi: https://doi.org/10.1007/s11696-016-0031-5.

25. G. Zeng, M. Yu, Y. Chen, D. Huang, J. Zhang, H. Huang, R. Jiang, Z. Yu, Effects of inoculation with Phanerochaete chrysosporium at various time points on enzyme activities during agricultural waste composting, Bioresour. Technol. 101 (2010) 222-227, doi: https://doi.org/10.1016/j.biortech.2009.08.013.

26. P. K. Foreman, D. Brown, L. Dankmeyer, R. Dean, S. Diener, N. S. Dunn-Coleman, F. Goedegebuur, T. D. Houfek, G. J. England, A. S. Kelley, H. J. Meerman, T. Mitchell, C. Mitchinson, H. A. Olivares, P. J. M. Teunissen, J. Yao, M. Ward, Transcriptional Regulation of Biomass-degrading Enzymes in the Filamentous Fungus Trichoderma reesei, J. Biol. Chem. 278 (2003) 31988-31997, doi: https://doi.org/10.1074/jbc. M304750200.

27. J. Pérez, J. Muñoz-Dorado, T. de la Rubia, J. Martínez, Biodegradation and biological treatments of cellulose, hemicellulose and lignin: an overview, Int. Microb. 5 (2002) 53-63, doi: https://doi.org/10.1007/s10123-002-0062-3.

28. J. Venglovsky, N. Sasakova, M. Vargova, Z. Pacajova, I. Placha, M. Petrovsky, D. Harichova, Evolution of temperature and chemical parameters during composting of the pig slurry solid fraction amended with natural zeolite, Bioresource. Technol. 92 (2005) 181-189, doi: https://doi.org/10.1016/j. biortech.2004.05.006.

29. C. Sundberg, S. Smårs, H. Jönsson, Low pH as an inhibiting factor in transition from mesophilic to thermophilic phase in composting, Bioresource. Technol. 95 (2004) 145-150, doi: https://doi.org/10.1016/j.biortech.2004.01.016. 


\section{SUMMARY}

\section{Composting of Agroindustrial Waste, Biowaste and Biodegradable Municipal Solid Waste in Adiabatic Reactor}

Dajana Kučić Grgić, ${ }^{a^{*}}$ Felicita Briški, ${ }^{a}$ Vesna Ocelić Bulatović, ${ }^{b}$ Marija Vuković Domanovac, ${ }^{a}$ Tomislav Domanovac, ${ }^{c}$ Monika Šabić Runjavec, ${ }^{a}$ Martina Miloloža, a and Matija Cvetnića

The aim of this work was biological treatment of agroindustrial waste (P1), biowaste (P2) and biodegradable municipal solid waste (P3) by the composting process in adiabatic reactor during 21 days. In experiments $\mathrm{P} 1, \mathrm{P} 2$, and $\mathrm{P} 3$, a maximum temperature of 52,55 , and $57^{\circ} \mathrm{C}$ was reached, and the thermophilic phase lasted 8,5 , and 6 days. The cumulative evolved $\mathrm{CO}_{2}$ and $\mathrm{NH}_{3}$ was 122, 407, and $389 \mathrm{~g} \mathrm{~kg}_{\mathrm{vm}}{ }^{-1}$ and 89,148 , and $559 \mathrm{mg} \mathrm{kg}_{\mathrm{vm}}{ }^{-1}$, respectively. The $\mathrm{pH}$ value at the beginning of the process was in the neutral and at the end in the slightly alkaline domain. The substrate humidity increased by about $5 \%$, while the $\mathrm{C} / \mathrm{N}$ ratio decreased due to a decrease in the organic $\mathrm{C}$ content and an increase in $\mathrm{N}$ content. Consequently, a conversion of $48 \%, 71 \%$, and $56 \%$, respectively, was achieved in experiments P1, P2, and P3.

\section{Keywords}

Agroindustrial waste, biowaste, biodegradable municipal solid waste, composting process, adiabatic reactor

${ }^{a}$ Faculty of Chemical Engineering and Technology, University of Zagreb, Croatia ${ }^{\mathrm{b}}$ Faculty of Metallurgy, University of Zagreb,

Original scientific paper

c IPZ Uniprojekt TERRA d. o. o., Croatia Accepted September 3, 2019 